\title{
Income Smoothing Practices: Evidence from Banks Operating in OECD Countries
}

\author{
Neila Boulila Taktak (Corresponding author) \\ ESSECT - Unité DEFI - Université de Tunis \\ 4 Rue Abou-zakaria Hafsi, Montfleury 1089 Tunis \\ E-mail: neila_boulila@yahoo.fr \\ Ridha Shabou \\ King Saud University \\ P.O Box 2459 - Al-Riyadh 11451, Kingdom of Saudi Arabia \\ E-mail: rshabou@ksu.edu.sa \\ Pascal Dumontier \\ I.A.E of Grenoble, Pierre Mendès France University \\ B.P. 47, 38040 Grenoble Cédex 9 - France \\ E-mail: pascal.dumontier@iae-grenoble.fr
}

\begin{abstract}
_
Using a sample of 278 commercial banks operating in OECD countries, this paper shows that numerous banks smooth their earnings intentionally either by using loan loss provisions or by selling trading securities. These banks resort more to real income smoothing than to the artificial one. Results also indicate that the banks' propensity to smooth reported earnings depends on their exposure to prudential and curative constraints and on various institutional constraints. The degree of capitalization, the composition of regulatory equity capital and the presence of insured creditors motivate banks to smooth their results. This study also highlights that Anglo-Saxon accounting systems seem to favour smoothing behaviour probably because they provide discretion in reporting transactions.
\end{abstract}

Keywords: Artificial income smoothing, Real income smoothing, Curative and prudential banking regulations

JEL Classification: G21 - M41 - - G28

\section{Introduction}

The role that banks play in economic development is so important that they are constantly monitored by investors and supervisory authorities. If the concern of the former is to meet their expectations on capital revenue, the latter focus on ensuring the financial stability of the banking system. Accordingly, the evolution of the net income constitutes one of the main indicators that allow the assessment of the bank's profitability and the financial stability of the economy. Bank managers will then be motivated to minimize the earnings fluctuation over time. Income smoothing constitutes a practice that allows banks to consolidate their financial bases and to comply with the regulatory requirements.

If there are many studies related to income smoothing practices conducted by industrial and commercial firms, those devoted to income smoothing in banking industry are far fewer. Most of them are generally interested in American banks to identify these practices while emphasizing the relationship between provisions policy and net income (Scheiner, 1981; Greenawalt and Sinkey, 1988; Ma, 1988; Bhat, 1996 ; Anandarajan et al., 2003 ; Anandarajan et al., 2005). Other studies are focused on investigating the determinants of bank income smoothing. Kanagaretnam et al. (2004) show that the need to obtain external financing and the concern for preserving the post of a manager seem to be the explanatory factors of income smoothing for American banks over the period 1987-2000. Beatty and Harris, 1999 and Beatty et al., 2002 find that the nature of control, the level of indebtedness, listing, the size, etc. are the main determinants of income smoothing. All these authors do not take into consideration the effect of the prudential and curative banking regulations in the tested explanatory variables. The restriction on the capital adequacy ratio and the presence of insurance deposit are the main mechanism of banking regulation, which set up a security belt for the banking system so as to avoid financial crises and the negative externalities associated. Fonseca and Gonzalez (2008) can be considered as pioneers in showing that banking regulation and supervision may affect bank income smoothing by managing loan loss provisions. The purpose of this research is to investigate how prudential and 
curative banking regulation could affect the financial structure of the bank and therefore the impact on income smoothing practices using individual data for the commercial banks operating in OECD countries. It is aimed mainly at verifying whether or not managers may smooth their results in their real or artificial form by respectively managing loan loss provisions and selling trading securities in order to meet the requirements of the banking regulation. This study is particularly relevant in evaluating the effect of the first pillar of the new Basel Capital Accord (Basel II) on the reliability of banks' financial statements since the standardized approach to credit risk in this New Basel Accord is conceptually similar to the 1988 agreement.

We use a methodology of Beidleman's coefficient (1973) and Eckel's coefficient (1981) to identify the smoothing banks operating in ODCE countries and a logistic regression model to estimate the effect of several variables related to prudential and curative banking regulations on income smoothing. The results indicate that commercial banks seem to resort more frequently to real income smoothing than to the artificial one, by selling trading securities rather than managing loan loss provisions. Our findings also show that the banks' propensity to smooth reported earnings depends on their exposure to prudential constraints, on debt constraints and on various institutional constraints.

The rest of the paper is structured as follows. Section 2 develops hypotheses that will be submitted to validation. Section 3 describes the data and the variables used. Section 4 presents the results related to the identification of income smoothing practices in its two forms: artificial and real. Section 5 analyses the banking regulatory determinants of the smoothing practices. Lastly, section 6 concludes the paper.

\section{Theoretical framework and hypotheses development}

The banking regulation consists of several arrangements which determine the functioning of the financial services market and avoid bank failure. These arrangements consist of prudential and curative regulations. The prudential regulation is of a preventive nature and its effect is to homogenize the competitive conditions between banks in different countries. The curative regulation consists of the deposit insurance and the function of the last resort lender provided by the central bank. These regulations are triggered when the bank starts having liquidity and /or solvency problems over time.

\subsection{Prudential banking regulation}

The pivotal element of the prudential banking regulation is to force internationally active banks to hold a required minimum of $8 \%$ of capital equity to risk-weighted assets (capital adequacy ratio) as defined by the Basel agreement (1988). Under this agreement, equity capital is made up of the primary equity capital (Tier I) and the complementary equity capital (Tier II), both of which are calculated on a non-consolidated basis. Tier I consists primarily of the permanent shareholders' equity. It includes equity capital, disclosed reserves (legal reserves, statutory reserves, free reserves, etc.) and retained earnings. Limited to $100 \%$ of the primary equity capital, the complementary equity capital includes the undisclosed reserves, the revaluation reserves, the hybrid (debt or equity) capital instruments, the subordinated term debt instruments and the general loan loss reserves limited to a maximum of $1.25 \%$ of risk weighted assets (Basel agreement, 1988). In the framework of this regulation, managers may smooth their results to meet the prudential banking requirements.

\subsubsection{Capital adequacy ratio and income smoothing}

As a component of the capital adequacy ratio, net income can be manipulated by managing loan loss provisions and/or selling securities. These two techniques of earnings management are the most used in empirical literature (Greenawalt and Sinkey, 1988; McNichols et al., 1988; Wahlen, 1994; Beatty et al., 1995 for American banks, Naciri, 2002 for Canadian banks; Shrieves and Dahl, 2003 and Agarwal et al., 2006 for Japanese banks).

According to the Basel agreement (1988), when the expected preliminary result is low, managers may reduce the amount of loan loss provisions and opt for the sale of transaction securities to reach and keep the minimal level of solvency ratio. This minimum required is the limit from which the supervisory authority interferes in the management of the bank. Banks with a solvency ratio below minimum are subject to a controller's interference, while the ones highly capitalized benefit from passivity (Dewatripont and Tirole, 1993).

Empirically, the results about the effect of the level of bank capitalisation on income smoothing are mixed but support the theoretical predictions. If Ramesh and Revsine (2001) and Shrieves and Dahl (2003) find that the banks weakly capitalized use either loan loss provisions or securities gains to smooth their results, Kanagaretnam et al. (2004), however, find that the banks highly capitalized banks use these techniques. Then we support the hypothesis that banks well or poorly capitalized are more likely to smooth their results.

H1: All other things being equal, the propensity of banks to smooth their results is all the stronger since the level of their solvency ratio is very low (Note 1) or high. 


\subsubsection{Composition of banking equity capital and income smoothing}

In addition to the impact of the capital adequacy ratio, the composition of the regulatory equity capital is also likely to affect bank income smoothing. When the complementary banking equity (Tier II) gets closer to the tolerated limit (that is $100 \%$ of the primary equity capital or Tier I), banks are compelled, after using up all of their means of consolidation by issuing subordinated securities or by resorting to the revaluation reserves, to broaden their primary equity capital either through an increase in their capital or an increase in the retained result. In this case, smoothing constitutes a suitable technique that enables banks to keep some stability at the level of their result both when the complementary equity gets closer to the primary equity capital and when the proportion of retained result is large.

H2-1: All other things being equal, the propensity of banks to smooth their income is all the stronger because the amount of their complementary equity gets closer to the amount of their primary equity capital.

H2-2: All other things being equal, the propensity of banks to smooth their income is all the stronger because the proportion of retained result is large.

It should be noted that, as far as we know, no earlier study has tested these two hypotheses about the impact of the regulatory equity components on income smoothing.

\subsection{Curative banking regulation}

Two mechanisms are generally used in the curative banking regulation. The first one, the Central Bank as the last resort lender, intervenes when the bank starts having serious long lasting liquidity problems. If some banks incur losses in their liquid assets and if they have used up their liquid assets or those accepted as guarantees, they cannot face up to their obligations without selling illiquid assets. The central bank lends these banks adequate liquid assets to restore the depositors' confidence and avoid a bank panic. The second curative mechanism is the deposit insurance, which ensures depositors against the failing risks of their banks. It makes sure the depositors will get back their deposits even in case the bank defaults. Therefore, the deposits insurance can prevent the rush for banks and panic brought about by the depositors' mass withdrawals (Beck and Laeven, 2006). We note that the implementation of this curative banking regulation may affect the bank's financial structure by distinguishing two types of creditors: insured (depositors) and non insured (interbank creditors (Note 2).

\subsubsection{Insured creditors and income smoothing}

Managers may smooth their reported results in the presence of insured creditors, for whom their receivables are explicitly insured by the deposit insurance. They are encouraged by the lack of control exerted by this category of creditors, which is generally small, incompetent, uninformed and victim of the problem of the stowaway (Dewatripont and Tirole, 1993). In this context, we estimate that the more the share of deposits held by insured creditors increases in the bank's financial structure, the stronger the income smoothing will be.

H3-1: All other things being equal, the propensity of banks to smooth their results is all the stronger because the level of deposits is high.

\subsubsection{Non insured creditors and income smoothing}

In contrast to the last case, bank managers are less motivated to smooth their earnings in the presence of non insured creditors. As interbank lenders are not covered by the deposits guarantee fund, they will be more motivated than depositors to monitor these manager's decisions, which may have a negative impact on income smoothing (Dewatripont and Tirole, 1993; Bhat, 1996).

H3-2: All other things being equal, the propensity of banks to smooth their results is all the weaker because the level of interbank indebtedness is high.

It's interesting to note that previous empirical studies focused mainly on the effect of debt on bank income smoothing without distinguishing between secured creditors and those not secured by deposit insurance. This study attempts to fill in this gap.

\subsection{Control variables}

Control variables such as size, listing on the Stock Exchange and origin of the legal system are also likely to affect bank income smoothing.

Banks are more subject to constant attention by the public authorities, especially when their results are fluctuating. Excessive increases may be detected as a signal of monopolistic practices. Important decreases may be a token of stress, and thereby encourage the regulatory authorities to intervene. Thus large banks will be motivated to smooth their results more than the small ones. The size of the bank is generally approximated by the Neperian logarithm of the total assets (Lnact). Besides, the results of the earlier empirical work are mixed. In the context of American 
banks, if Moyer (1990) and Bhat (1996) confirm that large banks appeal more to earnings management, Beatty and Harris (1999), however find that the bank size does not affect the manager' accounting practices.

\section{H4: All other things being equal, the propensity of banks to smooth their results increases with their size.}

Investors are expecting an increasing remuneration from one year to the other. They generally define their stock market investment strategies notably on the stock exchange price and dividends. The managers of the listed banks find themselves bound to smooth their results to meet the investors' expectations. This hypothesis is apprehended by a dummy variable (COT) which equals the value 1 if the bank is listed on a Stock Exchange and 0 otherwise.

H5: All other things being equal, listing on the Stock Exchange increases the intention of bank income smoothing.

Finally, the origin of the legal system may also have an impact on bank income smoothing. According to Meek and Saudagaran (1990), the legal system represents one factor among others which can explain the differences between the accounting systems. In the common law countries, the laws merely state general principles, leaving the judges a lot of freedom in their assessment when settling disputes. This is the system in effect in all Anglo-Saxon countries. On the other hand, the civil law countries are characterized by particularly detailed legislation that leaves much less room for interpretation. Thus, we expected the banks active in the common law countries $(\mathrm{LAW}=1)$ to get further involved in accounts manipulation, and consequently to smooth their results more than the banks operating in the countries of codified law (LAW $=0$ ).

H6: All other things being equal, the propensity of banks to smooth their results depends on the origin of the legal system.

\section{DATA}

\subsection{Sample}

The banks included in the sample are identified from the international database "Bankscope" composed of 17412 banks. Our main selection criterion consisted in establishing a homogeneous sample of banks operating in the Organization for Economic Co-operation and Development (OECD) countries to which the Basel agreement was applied. This covers internationally active banks which consist exclusively of large commercial banks. For this purpose, only commercial banks, leaving aside any other specialization, were selected, that is 7863 banks. In the same way, all the banks with total assets less than a billion American dollars have been ruled out. This brings the sample down to 2,061 banks. Only banks operating in OECD were selected in the sample, as these countries constitute the basic lot of the international exchange flows. Thus, the sample becomes 1418 banks. Then we selected all the banks with annual accounting data on a non consolidated basis (Note 3), which reduces the sample to 497 banks. To benefit from a long horizon to assess the intensity of income smoothing, we only accepted the banks for which we had available data from 1994 until 31 December 2002. This constraint reduced the sample to 471 banks. Taking into account the existence of several types of accounting and financial data presentation, we included only the information set out according to an identical format for all countries. The "Raw Data" extracted from the balance sheets, the profit and loss accounts and the annual report appendixes are turned into reprocessed data ("Global Summary Data" and "Global Detailed Data"). All of these treatments ensure the homogeneity of the data studied. Around 8 banks had to be eliminated because some data were not available to carry out this transformation properly. All balance-sheet and income statement data are presented in US dollars and in real prices for the period 1994-2002 (Note 4). Finally, the banks which set about changing their legal status during the period studied, especially those subject to merger or takeover bid, were not selected, which reduced the sample to 242 banks. Our consultation of, Bankers Almanacs data base (2002), on bank history, enabled us to raise our final sample to 278 banks. The sample constitution methods are summarized in table 1(Note 5).

\section{INSERT TABLE 1}

The U.S banks alone make up around 50\% of the sample banks. The German and Luxembourgian banks account for $10 \%$ of the sample each. The Italian, French, Spanish, British and Irish banks account for $4 \%$ of the sample each. These eight countries provide about $90 \%$ of the sample banks. The remaining $10 \%$ are shared out among 9 remaining countries.

\subsection{Variables definition}

The Variables of interest designed to validate the hypotheses described earlier are defined as follows. For hypothesis $\mathrm{H} 1$, the level of capital adequacy ratio is measured by a dummy variable (REG) which takes the value 1 for the banks highly and poorly capitalized (being respectively in the fourth and the first quartile of the capital adequacy ratio) and 0 for the banks of average capitalization (second and third quartile). As for hypothesis $\mathrm{H} 2-1$, the composition of the regulatory equity capital is approximated by the ratio between the complementary equity capital 
(Tier II) and the primary equity capital (Tier I). This hypothesis will be tested using a dummy variable (CFP) which takes the value 1 if the ratio (Tier II /Tier I) is superior or equal to the median and 0 otherwise. The two variables (REG and CFP) have been collected from the Bankscope database and by consulting the websites of the banks for which this information is missing. Hypothesis H2-2 is measured by the ratio of retained results over the bank's net income (RETNERDT). As regards hypothesis 3-1, a bank's insured level of debt (DEPOT) is apprehended by the ratio of the customer deposits over total assets. The level of non insured debt (INTBANK) related to hypothesis 3-2 is determined by the ratio interbank debts over total assets.

Table 2 summarizes the hypotheses, the measurement variables as well as the sign expected from the impact of the variables on income smoothing.

\section{INSERT TABLE 2 HERE}

\section{Detecting income smoothing practices}

The early literature (e.g. Scheiner, 1981 and Greenawalt and Sinkey, 1988) is focused mainly on detecting whether banks resort to income smoothing or not, without specifying whether it is natural or intentional. Natural smoothing results from an income generating process where as intentional smoothing results from the deliberate mangers' will to minimize variability of results over time. It is therefore relevant to choose the appropriate methodology to identify the smoothing banks, especially in the presence of mixed outcomes of the many US studies. In this paper, we suggest transposing the identification methods of the smoothing practices traditionally used and which have proved a success for the industrial and commercial firms. This approach is available in two stages. Firstly, we are interested in studying the variability of the object of smoothing so as to identify the group of smoothing banks. Secondly, we have to determine whether income smoothing is natural or intentional, and whether it is artificial or real in case it is intentional.

\subsection{Measuring the earnings variability}

The empirical studies consider indiscriminately two methods initiated by Eckel (1981) and Beidleman (1973) to measure the earnings variability. Beildleman's coefficients (called coefficients of determination) measure the correlation of the object of smoothing over time. Eckel's coefficients (called coefficients of variation) measure the variability of the object of smoothing with its average over time.

For Eckel's method, the first coefficient of variation (CV1) consists in dividing the standard deviation of change in net income over the sample period for each bank by the mean of its changes (Note ${ }^{6}$ ). The second (CV2) is the standard deviation of the changes in the net income over the sample period for each bank divided by the mean of the net income ( Note $^{7}$ ). We have chosen the second coefficient because it leads to the selection of a larger number of banks. Smoothing is supposed to be perfect when the variation coefficient is nil.

For Beidleman's method, the first model is linear and assumes a steady growth of the net income over time. The second is semi-logarithmic, which supposes a constant growth rate for the net income over time. However, this model eliminates the banks presenting negative net income even for a single year during the study period. For this reason, we have opted for the linear regression model to detect the smoothing banks. Smoothing is supposed to be perfect when the determination coefficient is equal to the unit.

Despite the various techniques available, smoothing can never be practically perfect. So, to select the smoothing banks, we adopt a graphical approach (Note ${ }^{8}$ ) following Chalayer and Dumontier (1995) (figures 1 and 2). The first break observed on the graphic allows the separation between the smoothing and non-smoothing banks.

Figure 1 shows the first break at the critical value of the unit for the variation coefficient. Consequently, a bank whose variation coefficient is less than or equal to the unit will be considered as smoothing. It will be classified non-smoothing otherwise. On this basis, 227 banks out of the 278 from the sample are considered smoothing their net income and 51 non smoothing. As for the determination coefficient, figure 2 does not appear any significant break. Transposing the smoothing curve to the histograms reveals three different phases. The curve is declining for a level of $\mathrm{R}^{2}$ less than 0.2. It picks up but quickly displays another minimum when $\mathrm{R}^{2}$ reaches 0.5 . Finally, from 0.5 , the curve sets about rising exponentially until $\mathrm{R}^{2}$ reaches 0.95 . Thus, to delimit the arbitrary, we prudently set the critical value at 0.5 , which allows the identification of 155 smoothing banks and 123 non smoothing banks.

Crossing the results from the variation coefficients with those from the determination coefficients allows the identification of 152 smoothing banks (55\% of the sample), 48 non-smoothing banks (17\% of the sample) and 78 banks with an ambiguous behavior. They are smoothing according to one criterion but they are not according to the other. Analyzing the evolution of the net income of each of these banks allows the detection of 7 cases of supplementary typical smoothing. These cases have not been detected by the two smoothing measurements used because the distribution of the results presents a unique and extremely strong break. This enabled us ultimately to 
identify 159 smoothing banks (i.e. $57 \%$ of the banks in the sample). We are now setting out to prove whether this income smoothing is natural or intentional.

\section{INSERT FIGURE 1 AND 2 HERE}

\subsection{Identifying artificial and real smoothing}

\subsubsection{Artificial smoothing}

Artificial smoothing, which result from manipulating accounting figures, is identified through the correlation test between residuals by using a three-stage sequence. The first one consists in regressing the net income on the time series to determine discretionary result.

$$
O L_{i t}=a_{O L i}+b_{O L i} X_{t}+U_{O L i t} \text { (1) }
$$

Where $\mathrm{OL}_{\mathrm{it}}$ is the net income of the bank $\mathrm{i}$ in the year $\mathrm{t}, \mathrm{X}_{\mathrm{t}}$ expresses the time variable at the year $\mathrm{t}$ and $\mathrm{U}_{\text {oLit }}$ is the residue between the published result and the estimated one.

The second stage consists in determining the discretionary loan loss provisions (Note 9) using an equation which explicitly models the non-discretionary portion of LLP (Wahlen, 1994; Beatty et al., 1995; Kanagaretnam et al., 2004).

$$
L L P_{i t}=b_{0}+b_{1} \Delta N P L_{i t}+b_{2} \Delta L O A N_{i t}+b_{3} L L A_{i t-1}+U L L P_{i t}
$$

Where $\mathrm{LLP}_{\mathrm{it}}$ is the loan loss provisions of bank $\mathrm{i}_{\mathrm{i}}$ in the year $\mathrm{t}, \Delta \mathrm{NPL}_{\mathrm{it}}$ is the change in the nonperforming loans of bank $_{i}, \Delta \operatorname{LOAN}_{\mathrm{it}}$ is the change in the total loans of bank $\mathrm{i}$ and $\mathrm{LLA}_{\mathrm{it}-1}$ represent the loan loss reserves of bank $\mathrm{i}$ in year $\mathrm{t}-1$. ULLP $\mathrm{Hit}_{\mathrm{t}}$ is the residual from equation (2) representing the discretionary LLP of the bank $\mathrm{i}$ in the year $\mathrm{t}$ (Note 10). According to Greenawalt and Sinkey (1988) and Wahlen (1994), $\Delta \mathrm{NPL}_{\mathrm{it}}, \Delta \mathrm{LOAN}_{\mathrm{it}}$ and $\mathrm{LLA}_{\mathrm{it}-1}$ can generally be considered as proxies for the bank credit risk and will be associated by a positive coefficient.

The third stage consists in calculating each of Pearson's correlation coefficient between the two residuals. A positive and significant correlation means that banks resort to artificial income smoothing. Indeed, when the published result is superior to the objective one $\left(\mathrm{U}_{\text {olit }}>0\right)$, the manager increases LLP $\left(\mathrm{ULLP}_{\mathrm{it}}>0\right)$.

The results indicate that only twenty six banks $(17 \%)$ present a positive and significant correlation and therefore resort to artificial smoothing. The use of the loan loss provisions as unique and specific accruals leads to the identification of a small number of smoothing banks. Furthermore, this technique is derived from a static provision policy which is late in appreciating the bank credit risk and increases the results variability (Jaudoin, 2001).

\subsubsection{Real smoothing}

Real smoothing, which results from manipulating real activities, is identified through Bartov's approach (1993). When the earnings to be published in the current year are less than those of the previous year, the manager will be motivate to sell transaction securities (Note 11) which enable him to get capital gains. In the opposite case, the manager does not appeal to such a decision. Therefore, real smoothing is reflected by a negative correlation between the trading securities gains and variations in the result before these gains.

The results show that forty-eight banks (40\%) present a negative and significant correlation coefficient and then resort to real smoothing. The greater use of real smoothing compared to the artificial one, reveals the managers'high discretion in selling trading securities and realizing capital gains while escaping from the auditors' control. In addition to the loan loss provisions technique, trading securities gains can be considered as a supplementary tool for manager to smooth their results intentionally. This outcome highlights the importance of real smoothing in banks which was largely ignored in earlier resarch.

To conclude with, sixty three banks of our sample smooth their net income intentionally (i.e. $40 \%$ ): fifteen banks use artificial smoothing, thirty seven banks resort to real smoothing and eleven banks use both of them. It's important to note that about the thirty-six banks which appeal to artificial smoothing, just one third are American while for real smoothing, out of the forty-eight, only $43.75 \%$ are American.

\section{Determinants of the bank income smoothing}

We use the logistic regression model to estimate the impact of banking regulation variables on intentional income smoothing. The dependent variable is qualitative: it takes the value 1 for the smoother banks and 0 otherwise (Note 12). Since the model requires the absence of multicolinearity between the explanatory variables, the two debt measurements which indicate a high Pearson's correlation coefficients, will not be integrated into the same regression. Two models are then tested separately. 


$$
\begin{aligned}
& y_{i}=\beta_{1} R E G+\beta_{2} C F P+\beta_{3} R E T N E R D T+\beta_{4} D E P O S I T+\beta_{5} L N A C T+\beta_{6} C O T \\
& +\beta_{7} L A W+b_{8} \sum_{j=1}^{17} \text { country }_{j}+\beta_{9} \sum_{t=1994}^{2002} Y E A R \quad(\text { Model } 1) \\
& y_{i}=\beta_{1} R E G+\beta_{2} C F P+\beta_{3} R E T N E D R T+\beta_{4} I N T B A N K+\beta_{5} L N A C T+\beta_{6} C O T \\
& \left.+\beta_{7} L A W+b_{8} \sum_{j=1}^{17} \text { country }_{j}+\beta_{9} \sum_{t=1994}^{2002} \text { Year (Model } 2\right)
\end{aligned}
$$

Where $\mathrm{Yi}$ is a dummy variable that takes the value 1 if the bank resort to intentional smoothing and 0 otherwise, $\mathrm{REG}=1$ for the banks highly and poorly capitalized (located respectively in the fourth and the first quartile of the capital adequacy ratio) and 0 for the banks moderately capitalized (second and third quartile), CFP $=1$ if the ratio (Tier II / Tier I) is superior or equal to the median and 0 in the opposite case, RETNERDT = retained results / net income, DEPOSIT $=$ Customer deposits $/$ Total assets, INTBANK $=$ Interbank debts $/$ Total assets, Lnact $=$ logarithm of the total assets, COT $=1$ if the bank is listed and 0 otherwise, LAW $=1$ if the bank operates in a common law country and 0 if bank operates is in a codified law country, $\sum_{j=1}^{17}$ Country $_{j}$ is a set of country dummy variables controlling for specific differences across countries and $\sum_{t=1994}^{2002}$ Year $_{t}$ is a set of dummy time variables controlling country's economic conditions.

\section{INSERT TABLE 3 HERE}

Table 3 shows the results of the logistic regression model. $76,8 \%$ of the smoothing banks are correctly classified by the model which presents a highly significant chi-square value (less than $0.01 \%$ ). Furthermore, the coefficients seem to be stable in both models, which confirms the robustness of our findings.

The variables proxies' of the prudential banking regulation (REG, CFP and RETNERDT) have the expected positive coefficients, indicating that bank managers intend to smooth their results for the purpose of meeting banking regulation requirements. Our findings confirm that the level of capital adequacy ratio and the composition of bank equity capital constitute the two mainly leverage of this regulation, which affect managers discretion relating to the loan loss provisions and the trading securities gains. Firstly, banks highly or poorly capitalized intend to reduce the loan loss provisions and resort more to selling trading securities to minimize the variability of their income and to be in conformity with regulation. Income smoothing constitutes an accounting practice used either by the highly capitalized banks which benefit from the passiveness of the control institutions, or by the weakly capitalized ones which are subject to excessive control though. This conclusion is very interesting insofar as it allows reconciliation with the previous empirical results that were mixed (Ramesch and Revsine, 2001; Kanagaretnam et al., 2004). Secondly, when the complementary equity gets closer to the primary equity and the retained earnings are high, bank managers will be urged to smooth their results intentionally. Income smoothing then constitutes a suitable technique that allows managers to broaden their primary equity capital because the bank's ability to increase its equity would be based on its ability to choose a reserve constitution policy. This behavior allows them accordingly to broaden their complementary equity in order to benefit once again from issuing hybrid securities and revaluation reserves. These findings confirm the hypothesis that respect of banking regulatory requirements motivates banks operating in OECD to smooth their results but they are in contradiction with the results found by Fonseca and Gonzalez (2008) in an international context. They show that stricter official supervision, and more private monitoring reduce the use of LLP to smooth earnings.

As regards the impact of the curative banking regulation, the results show that the coefficients for debt variables are as expected. The positive coefficient associated with the DEPOSIT measurement indicates that income smoothing is probable when the proportion of insured creditors becomes high, because of their passivity in controlling the managers' decisions. On the other hand, the negative coefficient associated with the INTBANK measurement means that income smoothing may be less probable when the proportion of non insured lenders increases. Our finding supports the previous results by Bhat (1996) and Kanagaretnam et al. (2004) conducted in the U.S. banks.

Finally, as far as control variables are concerned, results indicate that the legal system seems to be the most important variable that affects income smoothing. The banks active in the codified law countries have a greater tendency to intentionally smooth their results than those in the common law countries. The Continental European countries are characterized by a stronger conservatism in their evaluation methods. They have a preference for a cautious approach to the accounting measures so that it responds to the uncertainty of future events in contrast with a more optimistic or risk-taking approach which is typical of the Anglo-American countries. The size variable has a significant coefficient but in contrast to the theoretical prediction. This outcome confirms the mixed results of earlier writings. If Beatty et al. (1995) do not find any link between smoothing and size, Bhat (1996) finds a positive and 
statistically significant relationship between political visibility and income smoothing. In the same way, approximating the hypothesis of political visibility by size sounds hardly justified. The large-sized banks do not constitute perfect substitutes for the politically visible banks, especially in the regulated sector where State control is deeply felt either through the prudential or the curative banking regulations. All the others control variables seems to be non-significant.

\section{Conclusion}

This study reveals that a significant proportion of the commercial banks in OECD countries tend to smooth their results intentionally either by manipulating the loan loss provisions or by managing the trading securities gains when they consider their results inadequate. It also reveals that the resort to income smoothing strategies is determined both by banking regulatory factors and institutional ones. The former which include the curative and prudential banking regulations seem to have an impact on income smoothing practices. In fact, the banks poorly capitalized, those highly capitalized, those whose primary equity capital is insufficient, and those which have a high proportion of retained earnings get further involved in discretionary practices. Besides, this research highlights that income smoothing varies positively with insured deposits and negatively with non-insured debts. As for the institutional variables, it seems that the origin of the legal system is the key variable likely to affect income smoothing. Indeed, it is more common for the banks active in continental Europe to appeal to income smoothing than those operating in Anglo-American countries.

\section{References}

Agarwal S., Chomsisengphet S., Liu C. and Rhee S.G. (2006). "Earnings Management during distinct periods of capital demand: evidence from Japanese banks", International Review of Economics and Finance, Vol. 3, n⿳6, pp.1-15.

Anandarajan A., Hasan I. and Lozano-Vivas A. (2003). "The role of loan loss provisions in earnings management, capital management, and signalling: The Spanish experience”, Advances in International Accounting, Vol.16, pp. 43-63.

Anandarajan A., Hasan I. and Lozano-Vivas A. (2005). "Loan loss provision decisions : an empirical analysis of the Spanish depository institutions," Journal of International Accounting, Auditing and Taxation, Vol. 14, $\mathrm{n}^{\circ} 1$, pp. 55-77, 2005.

Bartov A. (1993). "The timing of asset sales and earnings manipulation”, The Accounting Review, Vol. 68, n4, pp.840-855.

Beatty A., Chamberlain S. and Maglolo J. (1995). "Managing financial reports of commercial banks: the influence of taxes, regulatory capital, and earnings", Journal of Accounting Research, Vol.33, n², pp.231-262.

Beatty, A. and Harris, D. (1999). "The effects of taxes, agency costs and information asymmetry on earnings management : A comparison of public and private firms", Review of Accounting Studies, Vol. 4, pp. 299-326.

Beatty, A. L., Ke B. and Petroni K. R. (2002). "Earnings Management to Avoid Earnings Declines across Publicly and Privately Held Banks", The Accounting Review, Vol.77, pp.547-70.

Beck, T. and Laeven, L. (2006). "Resolution of Failed Banks by Deposit Insurers: Cross-Country Evidence", Working Paper, World Bank Policy Research, n³920.

Beidleman, C. (1973). "Income smoothing: the role of management", The Accounting Review, Vol. 48, n4, pp. 653-667.

Bhat, V.N. (1996). "Banks and income smoothing: an empirical analysis", Applied Financial Economics, nº, pp. 505-510.

Chalayer S. and Dumontier P. (1994). "Identification et motivations des pratiques de lissage des résultats comptables des entreprises françaises cotées en bourse”, Ph.D. in Management Science, Saint-Etienne University.

Dewatripont, M. and Tirole, J. (1993). La Réglementation prudentielle des Banques, Editions Payot Lausanne, 177 p.

Eckel, N. (1981). "The income smoothing hypothesis revisited”, Abacus, pp. 28-40.

Fonseca, A.R. and Gonzalez F. (2008). "Cross-country determinants of bank income smoothing by managing loan-loss provisions”, Journal of Banking and Finance, Vol.32, pp.217-228.

Greenawalt, M.B. and Sinkey, J.F. (1988). "Bank loan-loss provisions and income smoothing hypothesis: an empirical analysis, 1976-1984", Journal of Financial Services Research, Vol.1, pp. 301-318. 
Jaudoin, O. (2001). "Une proposition pour améliorer la stabilité : le provisionnement dynamique", Bulletin de la Banque de France, n95, November, pp. 109-120.

Kanagaretnam K., Lobo G.J. and Mathieu R. (2004). "Managerial incentives for income smoothing through bank loan loss provisions", The Review of Accounting and Finance, Vol. 3, n ${ }^{\circ}$ 1, pp. 128-148.

Ma, C.K. (1988). "Loan loss reserves and income smoothing: the experience in the US banking industry", Journal of Business Finance and Accounting, Vol. 15, pp. 487-497.

McNichols M., Maureen F. and Wilson G.P. (1988). "Evidence of earnings management from the provision for bad debts", Journal of Accounting Research, Vol.26, pp.1-31.

Meek, G.K. and Saudagaran, S.M. (1990). "A survey of research on financial reporting in a transnational context", Journal of Accounting Literature, Vol. 9, pp. 394-402.

Moyer S. (1990). "Capital adequacy ratio regulations and accounting choices in commercial banks", Journal of Accounting and Economics, Vol.13, pp.123-154.

Naciri A. (2002). "Earnings management from bank provisions for loan losses", Working Paper, University of Quebec, no 4-2002.

Ramesh K. and Revsine L. (2001) "The Effects of Regulatory and Contracting Costs on Banks Choice of Accounting Method for Other Postretirement Employee Benefits", Journal of Accounting and Economics, Vol. 30, pp. 159-186.

Scheiner, J.H. (1981) "Income smoothing : an analysis in the banking industry", Journal of Bank Research, Vol. 12, pp. 119-123.

Shrieves, R.E. and Dahl, D. (2003) "Discretionary Accounting and the behaviour of Japanese banks under financial distress", Journal of Banking and Finance, Vol. 27, pp. 1219-1243.

Wahlen J.M. (1994) "The nature of information in commercial bank loan loss disclosures", The Accounting Review, Vol.69, no 3, pp.455-478.

\section{Notes}

Note 1. Let's point out that the word "weak" must be understood not less than $8 \%$, which represents the legal minimum required.

Note 2. Interbank deposits correspond, on the one hand to very short term operations between the banks with liquid assets surpluses and those which are short of them temporarily and on the other hand to financing commercial operations between the non-financial firms. These operations lead banks to have credit lines with a very large number of banking correspondents (Dewatripont and Tirole, 1993).

Note 3. According to Basel II agreement, the use of consolidated accounting information constitutes the best means of preserving the integrity of equity and ruling out any possibility of dual recognition within the banks that have branches.

Note 4. The study period was 9 years $(1994-2002)$. This choice is not arbitrary and is justified essentially by the fact that 1988 - 1992 was considered as a transition period for the implementation of Basel I. Cooke ratio was set at $7.25 \%$ at the end of 1990 and reached the limit of $8 \%$ only at the end of 1992 . We have not included the years following 2003 in our study period, as they are characterized by several events (11 September, the war in Iraq, etc.) likely to load down the banks' activities. In addition to that, the European commission has conducted a series of banking reforms and accounting regulation since 2004 that may affect the banks' accounting policy.

Note 5. The countries that compose the sample are 17 namely: United States, Italy, France, Spain, United Kingdom, Germany, Luxembourg, Ireland, New Zealand, Poland, Switzerland, South Korea, Portugal, Hungry, Mexico, Norway and the Netherlands. CV2it $=\sigma(\Delta$ OLit $) / \mathrm{m}(\mathrm{OLit})$

Note 6. $\mathrm{CV} 1$ it $=\sigma(\Delta$ OLit $) / \mathrm{m}(\Delta \mathrm{OLit})$

Note 7. CV2it $=\sigma(\Delta$ OLit $) / \mathrm{m}(\mathrm{OLit})$

Note 8. Previous studies set the threshold of 1 to distinguish between smoothing and non smoothing banks. If the coefficients of variation and determination are less than one, firms are identified as smoothers and 0 otherwise.

Note 9. This technique is largely used by the previous studies (Scheiner, 1981; Greenawalt and Sinkey, 1988; Bhat, 1996).

Note 10. To avoid the problem of heteroscedasticity, all the variables of the model are standardized by the total loans at the beginning of year, following Kanagaretnam et al. (2004). 
Note 11. The choice of trading securities gains is justified in their degree of liquidity. They can be easily transferred for the unique purpose of realizing capital gains when the result is considered inadequate or even realizing capital loss in the opposite case (Kanagaretnam et al. 2004). These securities allow managers to have an effective means of manipulation through the sales timing.

Note 12 . We have tested the same model by comparing the banks whose results are intentionally smoothed to those whose results are naturally smoothed or not smoothed at all. The results obtained being qualitatively similar to those commented on here.

Table 1. Sample selection methods

\begin{tabular}{lr}
\hline Selection criteria sample & Numbers \\
\hline Bankscope's initial population (2003) & 17412 \\
Only commercial banks are accepted & 7863 \\
Principals banks & 2061 \\
Banks of the OECD member countries & 1418 \\
Banks with accounting information on a non-consolidated basis & 497 \\
Study period: 1994 - 2002 & 471 \\
Types of accounts available in "Global Data" format & 463 \\
Banks that did not carry out changes in their legal form over the period & 242 \\
Increased banks included in the sample by consulting the Bankers Almanacs & 278 \\
on the bank history &
\end{tabular}

Table 2. Summary of hypotheses, measurement of variables and expected sign

\begin{tabular}{llc}
$\begin{array}{l}\text { Variables related to the banking } \\
\text { regulation }\end{array}$ & Measurement of variables & Expected sign \\
\hline $\begin{array}{l}\text { H1: Level of the capital adequacy } \\
\text { ratio }\end{array}$ & $\begin{array}{l}\text { REG }=1 \text { for the banks highly and poorly capitalized (being set } \\
\text { respectively in the fourth and the first quartile of the solvency ratio) } \\
\text { and } 0 \text { for the banks fairly capitalized (second and third quartile) }\end{array}$ \\
$\begin{array}{ll}\text { H 2-1: Proportion of Tier II to Tier I } \\
\text { CFP }=1 \text { if the ratio (Tier II / Tier 1) is superior or equal to the } \\
\text { median and } 0 \text { otherwise }\end{array}$ & RETNERDT = Retained results / Net income & + \\
H 2-2: Retained results & DEPOSIT $=$ Customers' deposits / Total assets & + \\
H 3-1: Insured creditors & INTBANK = Interbank debts / Total assets & + \\
H3-2: Non insured creditors & Measurement of variables & + \\
\hline Control variables & Lnact $=$ Logarithm of the total assets & + \\
\hline H4: Size & COT $=1$ if the bank is listed and 0 otherwise & + \\
H5: Listing & LAW $=1$ if the bank operates in a common law country and 0 if & + \\
H6: Origin of the legal system & bank operates in the Roman-Germanic law. & + \\
\hline
\end{tabular}

Table 3. Results of the logistic regression on income smoothing determinants

\begin{tabular}{llllll}
\hline Variables & Predicted signs & Model $(1)$ & \multicolumn{3}{l}{ Model (2) } \\
\hline REG & + & 0,547 & $0,0851^{*}$ & 0,726 & $0,014^{* * *}$ \\
CFP & + & 0,541 & $0,088^{*}$ & 0,593 & $0,0470^{* *}$ \\
RETNERDT & + & 1,165 & $0,095^{*}$ & 1,440 & $0,035^{* *}$ \\
DEPOT & + & 5,332 & $0,00^{* * *}$ & & \\
INTBANK & - & & & $-4,555$ & $0,096^{*}$ \\
Lnact & + & $-0,310$ & $0,047^{* *}$ & $-0,517$ & $0,000^{* * *}$ \\
COT & + & 0,304 & 0,578 & 0,219 & 0,676 \\
DROIT & + & $-0,862$ & $0,058^{*}$ & $-1,067$ & $0,037^{* *}$ \\
Year dummies & ---- & Yes & & Yes & \\
Country dummies & & Yes & & Yes & \\
Constant & ---- & 60,914 & 0,679 & 32,99 & 0,812 \\
\hline
\end{tabular}

Regressions are estimated using logistc estimation. The dependant variable is a dummy variable that takes the value 1 if the bank resorts to intentional smoothing and 0 otherwise. $\mathrm{REG}=1$ for the banks highly and poorly capitalized (located respectively in the fourth and the first quartile of the capital adequacy ratio) and 0 for the banks moderately capitalized (second and third quartile); $\mathrm{CFP}=1$ if the ratio (Tier II / Tier I) is superior or equal to the median and 0 in the opposite case; RETNERDT = retained results / net income; DEPOSIT $=$ Customer deposits $/$ Total assets; INTBANK $=$ Interbank debts $/$ Total assets; Lnact $=$ logarithm of the 
total assets; COT $=1$ if the bank is listed and 0 otherwise; LAW $=1$ if the bank operates in a common law country and 0 if bank operates is in a codified law country; Year dummies $=1994, \ldots, 2002$; Country dummies : a dummy variable for each country, ***: significant at $1 \%$; **: significant at $5 \%$; *: significant at $10 \%$.

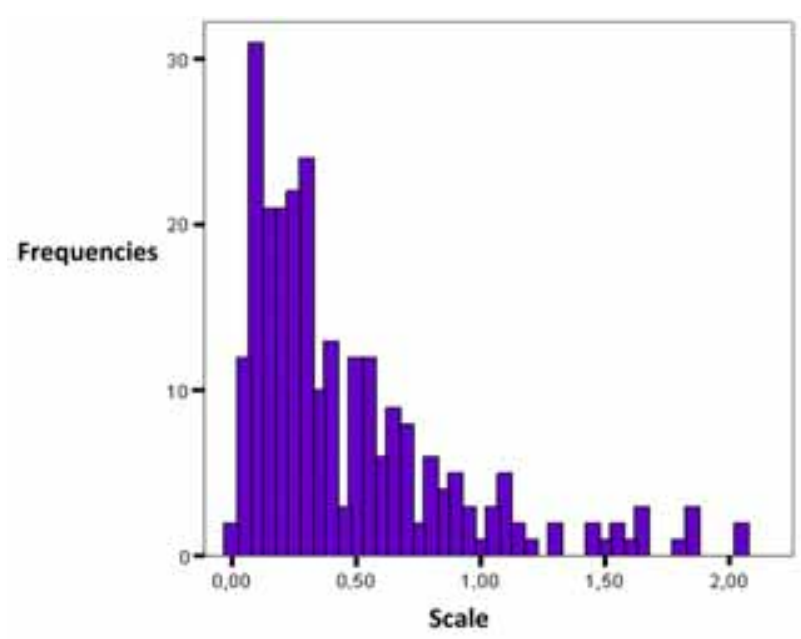

Figure 1. Histogram of the variation coefficients

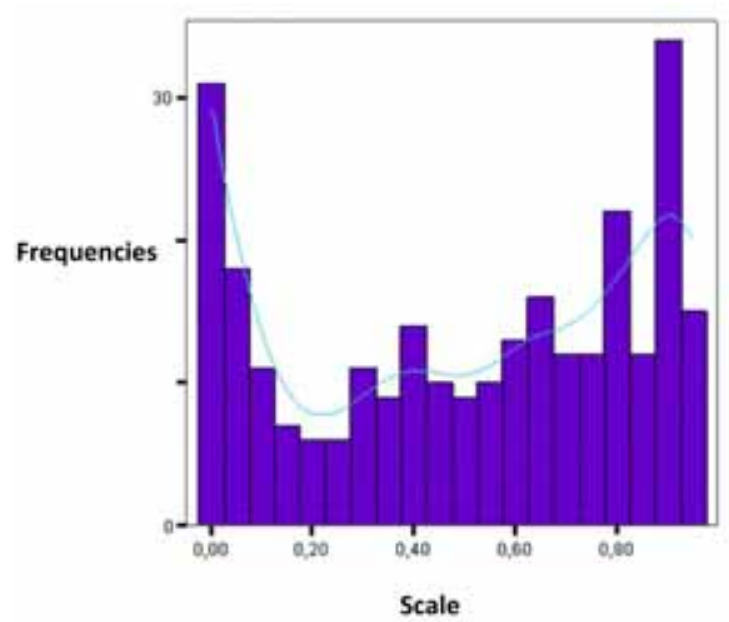

Figure 2. Histogram of the determination coefficients 